\title{
LA PRONÚNCIA CATALANA DEL LLATÍ
}

\section{THE CATALAN PRONUNCIATION FOR LATIN}

\section{LA PRONUNCIACIÓN CATALANA DEL LATÍN}

\section{Joan Grimalt i Santacana}

Escola superior de música de Catalunya

Ben mirat, la pronunciació del llatí no és més difícil que la de l'italià $i$ ho és molt menys que la del francès i de l'anglès.

Antoni SeVA

\section{Resum}

Aquest article respon a la necessitat d'un standard fonètic per al llatí que, per tot de motius, no ha quallat en l'àmbit lingüístic català. Va dirigit sobretot als cantants o directors corals que desitgin pronunciar correctament un text en llatí fent justícia, alhora, al sistema fonològic català. ${ }^{1}$

Després d'exposar la situació de dèficit, i com s'hi ha arribat, es revisen les propostes anteriors, i per què no satisfan les necessitats dels cors i dels solistes catalanoparlants. Finalment, després de distingir els tres casos bàsics amb què un intèrpret actual es pot trobar, pel que fa a un text llatí, s'argumenten i es presenten les solucions que, partint del que ha escrit Antoni SEVA (1994, 2011), semblen més útils i adients.

L'article es clou amb una sèrie de taules, per facilitar-ne la consulta expeditiva, i amb la transcripció fonètica de l'Ordinari de la missa catòlica, com a exemple pràctic.

\section{Paraules clau}

Llatí, català, fonètica, gramàtica històrica, Antoni SEVA, pronúncia.

1 Moltes gràcies al Dr. Antoni SEVA per les seves inestimables observacions, en revisar aquest text. El professor SEVA és una de les màximes referències catalanes de la llengua llatina. Autor del diccionari Llatí-Català (1994), entre altres. Moltes gràcies també al Dr. Antoni Bosch-Veciana, i al doctorand Eloi Creus, per llur lectura atenta i crítica.

\section{Abstract}

The article responds to the need of a Catalan standard pronunciation for Latin, which for several historical reasons could not be established so far in the Catalan speaking countries. It addresses above all singers and choral leaders who wish to pronounce correctly a Latin text while doing justice to the phonological Catalan system.

After exposing the deficitary situation, and its possible causes, some former proposals are critically revised, as to why they do not satisfy the needs of Catalan-speaking choirs and soloists. Fina1ly, after distinguishing the three basic cases with which a current interpreter is faced, when dealing with a Latin text, some suitable and useful solutions are presented and discussed. These are based on the works of Antoni SEVA (1994, 2011).

The article closes with some tables to facilitate a quick and simple reference, and with the phonetic transcription of the Catholic Ordinarium, as a practical example.

Key words

Latin, Catalan, Phonetics, Historical Grammar, Antoni SEVA, Pronunciation. 


\section{Resumen}

Este artículo responde a la necesidad de un standard fonético para el latín que, por motivos varios, no ha cuajado en el ámbito lingüístico catalán. Va dirigido sobre todo a cantantes y directores corales que deseen pronunciar correctamente un texto en latín haciendo justicia, a la vez, al sistema fonológico catalán.

Después de exponer la situación de déficit, y sus posibles causas, se revisan las propuestas anteriores, y por qué no satisfacen las necesidades de coros y de solistas catalanohablantes. Finalmente, después de distinguir los tres casos básicos con que un intérprete

\section{La situació actual, i com s'hi ha arribat}

Quan un cantant o un director coral de qualsevol país es troben amb un text llatí, normalment, la seva llengua materna ja els soluciona la qüestió de com pronunciar-lo. La condició de lingua franca durant tants segles ha fet que tot el món occidental se la senti seva, fins avui. Cada llengua ha trobat la manera de pronunciar-la, no només cantant, sinó també a l'escola o a la universitat, d'una manera que sigui coherent amb el propi repertori fonètic. Pel mateix motiu que es van imposant les òperes en la llengua original, i les pel-lícules subtitulades i no doblades, actualment és costum de cantar, aquí i arreu, "a l'alemanya" les misses de Mozart, Haydn, Beethoven o Schubert; o "a la francesa" les obres litúrgiques dels autors que les van pensar en francès ${ }^{2}$. Hi ha un manual de Timothy McGee, Singing Early Music (2004), que explica en detall com fer-ho.

Com passa en altres àmbits, en català hi ha, en aquest terreny, un buit clamorós. El llibre de McGee, p.e., aclareix com pronunciar el llatí des del punt de vista francès, neerlandès, espanyol, anglès, alemany i italià. El català hi apareix, però no el llatí català, sinó només les obres -totes antigues- escrites en la nostra llengua, per si algú vol saber com pronunciar-les sense saber català. ${ }^{3}$

Les raons d'un tal buit són polítiques i històriques. El llatí ha quedat arraconat del seu ús litúrgic, en la majoria d'esglésies i monestirs, d'ençà del Concili Vaticà II (19621965). El català, al seu torn, segueix amb la seva mala salut de ferro. Que aquesta supervivència hagi significat moltes pèrdues, i que la situació sòcio-lingüística, fins i tot al Principat, sigui precària, no hauria de sorprendre ningú. Ni tam-

2 I no només les obres d'autors francesos, sinó també, p.e., la Petite Messe Solennelle de Gioachino Rossini.

$3 \mathrm{Amb}$ un criteri molt discutible, McGee presenta com a standard la pronúncia més col·loquial del català central (oriental). Un símptoma més de l'estat de la llengua de Llull. Sovint, valdria més adoptar la fonètica occidental per a textos històrics catalans. Un exemple ben clar d'això són els madrigals de Joan Brudieu, mestre de capella de la Seu d'Urgell, sobre poesies del cavaller de Gandia Ausiàs Marc. Tots dos pronunciaven a la manera occidental. actual se puede encontrar, ante un texto latino, se argumentan y presentan las soluciones que, partiendo de los trabajos de Antoni SEVA $(1994,2011)$, parecen más útiles y apropiadas.

El artículo se cierra con una serie de tablas, para facilitar una consulta expeditiva, y con la transcripción fonética del Ordinario de la misa católica, como ejemplo práctico.

\section{Palabras clave}

Latín, catalán, fonética, gramática històrica, Antoni SEVA, pronunciación.

poc que la combinació llatí-català estigui per organitzar: és la d'una llengua romànica que molts voldrien morta, encara avui, amb una altra donada per morta, però que segueix fent de clau d'accés a una tradició europea que, si més no, val la pena conèixer, per avaluar-ne la vigència.

El fet és que, fins i tot en els monestirs catalans on el llatí encara té una tímida presència, $i$ en les interpretacions de caràcter professional dels nostres cors i cantants, se sent sovint a pronunciar amb totes les es i os tancades: *térra, *própter, etc. (sic). Per contra, seguint una idea de St. Pius X, a principis del segle XX, les consonants s'hi pronuncien a la romana. Podria ser, això darrer, un intent de distanciar-se de la resistència espanyola a deixar-se assimilar, a base de mantenir pronúncies castellanes tradicionals del llatí. L'europeisme ha estat sovint, a Catalunya, una via d'escapament subsidiària. La situació, però, és de fet absurda: per una banda, fem les consonants a la italiana; de l'altra, els catalanoparlants, a l'hora de pronunciar les vocals llatines, estem fent exactament el contrari que l'italià, que les obre totes. Aquesta actitud, normalment inconscient, és contrària no només a la majoria de les altres llengües, sinó sobretot al nostre sistema fonètic, $i$ també a la gramàtica històrica llatina. Potser s'explica per la influència de la "lengua de las cinco vocales", on se suposa que no hi ha es ni os obertes. ${ }^{4}$ Ras i curt: calia trobar una fórmula objectiva, que fes justícia als dos sistemes fonològics, llatí i català, sense submissions conscients ni inconscients.

\section{Solucions històriques}

A principis del s. XX, cal reconèixer l'esforç de Mn. Antoni M. Alcover, quan la llengua de St. Agustí tenia una presència en la vida social, cultural i religiosa que avui costa fins d'imaginar. Llavors era impossible de preveure que la litúrgia no seria en llatí per sempre. Per als capellans sensibles

$4 \mathrm{El}$ mateix fenomen s'observa a la ràdio i als mitjans catalans, a l'hora de pronunciar noms estrangers: dient ['merkal] en lloc de ['merkel], p.e., el nom de la cancellera no només sona més català, sinó també més alemany. 
a la llengua aquest era un tema candent, que va donar lloc a controvèrsies ben enceses. Ja aleshores, el castellà havia pogut infiltrar-se en una àrea com és la pronúncia del llatí, que avui sembla perifèrica, però que no ho va ser fins a la reforma litúrgica del Concili Vaticà II, als anys 60. Per això, Alcover, adalil de totes dues llengües, ja va proposar una pronúncia catalana del llatí, "aprofitant els avenços que la romanística havia fet en el terreny de la gramàtica històrica" (DOLS 2004: 13). Malgrat l'apassionament propi del personatge, val a dir que Alcover s'interessa bàsicament per les consonants, i que es limita a constatar que en català, hi ha tendència a obrir les vocals. Es refereix implícitament a les es i les os tòniques, que són les que mereixen una atenció especial, i ho fa oblidant tot el domini occidental, on aquesta tendència és ben diferent de la parla oriental que, per a ell, era la referència.

A més de la litúrgia, llavors ben viva en llatí, un altre punt essencial que distancia els escrits de Mn. Alcover dels nostres dies és la idea d'universalitat que ell preveia per a les seves conclusions. D'una postura "regionalista", propugnada els anys 1910/11, passa el 1920/22 a l'acatament de l'autoritat del papa, Pius X, que recomanava la pronúncia romana del llatí per a tot el catolicisme.

Fins a finals del s. XIX, a Europa era corrent pronunciar el llatí cadascú a la seva manera (cf. BRITTAIN 1934). Al motu proprio "Tra le sollecitudini" (1903), sobre la música sacra, St. Pius X recomana restablir el cant gregorià i afavorir la polifonia clàssica, esmentant Palestrina, i estableix una pila de recomanacions i preceptes, des de la "pietat i probitat" dels homes -només homes, i nens- que cantaran al cor de l'església, fins a la prohibició d'instruments "frívols", com la percussió o el piano (!), però no esmenta la pronúncia del llatí. ${ }^{5}$ Sí que en parla en una carta de 1912 a l'arquebisbe de Bourges. En aquesta carta, citada per ALLEN (1965 i 1992, p. 108), Pius X, preocupat per una intel-ligibilitat del text litúrgic, i mogut per un desig d'universalitat, recomana a tothom imitar la manera italiana, o més precisament romana, de pronunciar el llatí eclesiàstic. Paradoxalment, aquest desig d'uniformitzar és el que acaba creant una separació entre llatí eclesiàstic i la resta d'usos del llatí; fins llavors -fins al tombant del s. XX, com a mínim-, a les esglésies es pronunciava majoritàriament igual que a la universitat $\mathrm{o}$ als jutjats: de maneres "regionals", és a dir segons la comunitat lingüística. Això, malgrat que la pronúncia erudita, o erasmiana, s'anava afermant arreu, a poc a poc.

5 Un motu proprio és un document signat personalment pel papa, i escrit per iniciativa pròpia - que és el que vol dir el nom.

\section{La reconstrucció d'Antoni Seva}

El punt de vista actual veu en la diversitat de pronúncies d'una mateixa llengua, que segueix ocupant un lloc fonamental en les Humanitats, una virtut més que un problema. I per tant reconeix sense ambages la situació de fet, que cada idioma que ha pogut ha establert un sistema fonològic propi, a l'hora de pronunciar en veu alta la llengua de Ciceró.

Històricament, és possible reconstruir una manera de dir el llatí pròpia de la llengua catalana, que devia ser corrent en èpoques en què les pressions del castellà i de l'italià no fossin determinants. Escriu Antoni SEVA (2011: p. 12):

L'evolució del llatí va donar lloc a diverses tradicions prosòdiques, més o menys estables, en les diferents regions de la llatinitat. [...] També hi ha hagut, naturalment, una tradició específica catalana; el pas del temps i les influències foranes, però, l'han enterbolida. Per tant, s'ha de restaurar, sistematitzar i unificar. Ha de ser una pronunciació independent, en particular, tant de la italiana com de la castellana i de la francesa, que han introduït en la catalana elements estranys, per contacte o per pressió. Ara bé, no s'han de perdre de vista els elements comuns a tota la llatinitat: de fet, moltes de les regles que es donaran aquí tenen validesa general; altres són peculiars del català.

El punt de partida del professor Antoni SEVA és ben diferent del de mossèn Alcover, entre altres coses perquè es proposa cercar una pronúncia catalana al marge del llatí litúrgic. Si la idea d'una pronúncia universal ha valgut només a partir del s. XX, és evident que, fins i tot en textos eclesiàstics, la pronúncia romana avui considerada habitual hauria de ser restringida a obres molt recents, i encara, suposant que hom es volgués acollir al suggeriment de Pius X (1903 - 1914). La proposta de SEVA, en canvi, serà útil per a les ràdios i televisions, per als professors d'humanitats, i per a moltes ocasions més, on el llatí hagi de sonar d'una manera catalana, diferent de la pronúncia clàssica universitària. Això inclou els textos litúrgics. A vegades, sembla que el Dr. SEVA estigui pensant més en compositors, creant llur propi text llatí, que en intèrprets, que ens trobem amb l'obra com a premissa. Per exemple, quan explica la silllabació llatina.

Permeteu-me un excurs sobre aquest detall. Imaginem el cas que el compositor s'equivoqués en una qüestió prosòdica. Només dos exemples. Eduard Toldrà, en alguns casos, va musicar poemes de Carner en una versió anterior a la definitiva, que contenen solucions que primer la normativa, i després el poeta, han acabat bandejant ${ }^{6}$. Quan la

6 P.e. Menta i farigola (1915), o Cançó incerta (1927). Cf. http:// www.eduardtoldrasoler.info/. 
prosòdia se'n veu afectada, això planteja la disjuntiva de seguir la norma lingüística, al preu de desfigurar el ritme o la melodia, o al contrari de prioritzar la frase musical, a costa d'una versió posterior, millorada, del mateix poeta. Un altre exemple és l'accentuació falsa del mot garofa$n i$, 'clavells', en un moment del tercer acte de Le nozze di Figaro. Mozart, compositor poliglot i sensible a qüestions prosòdiques -en francès, en llatí, en italià i en la seva llengua materna-, accentua la penúltima sílllaba d'aquest mot esdrúixol. Pot passar a tothom: el mot no porta accent gràfic. Com que és un recitatiu, la solució aquí és relativament fàcil. Però alguna vegada es troben mestres de capella amb errors de prosòdia llatina, que no es poden arreglar sense desfigurar el cant que han concebut. P.e. musicant * gra-tias, dues síllabes, en lloc de gra-ti-as. No crec que hi hagi cap intèrpret que dubti gens a passar per sobre de la norma lingüística, a favor de les decisions que ha pres el compositor, ni que siguin errònies. Aquests casos il·lustren la diferència de perspectiva, ben comprensible, entre un filòleg i un intèrpret musical.

Des d'aquesta perspectiva pragmàtica, i tancant l'excurs, caldrà distingir entre tres possibilitats: la pronúncia clàssica o acadèmica; la pronúncia romana o eclesiàstica recent; i la pronúncia catalana tradicional, reconstruïda a partir del llatí tardà.

\section{El llatí clàssic}

En el primer dels tres casos que estem examinant, el professor o l'estudiant de llatí, el magistrat o el cantant, tant si és de parla catalana com si no, s'enfronten a un text clàssic, i opten per la pronúncia que els estudiosos, des de finals del s. XIX fins a mitjan s. XX, han acabat establint com a "clàssica". A la universitat i a l'escola, on se segueix ensenyant i llegint Cèsar i Virgili, aquesta pronúncia clàssica o erasmiana està ben establerta, de fa anys, i per tot el món. S'ha anat imposant per sobre de les variants regionals, afavorida per l'historicisme romàntic i contemporani.

A més dels textos antics, la pronúncia acadèmica té un caràcter universal que en fa un molt bon standard. Per això, també pot servir per a textos ben recents: un exemple, adduït pel mateix Dr. SEVA, són les òperes en llatí del compositor vilafranquí Josep Soler (n. 1935). O l'oratori EEdipus Rex, d'Igor Stravinsky (1927), basat en la tragèdia de Sòfocles -originalment en grec-, $\mathrm{i}$ on els textos parlats es diuen en la llengua moderna del lloc on es representa la peça, però els textos cantats són en llatí.

Repassem breument els trets principals de la pronúncia clàssica. Les vocals i l'accent tònic mereixen una atenció especial, i en parlarem tot seguit. De moment, pel que fa a les consonants, tot està ben establert de fa temps. S'ofereixen només aquelles que poden plantejar algun dubte.

$C$ i $G$ sonen sempre igual-velars-, tant davant de $e, i$, $a$, com de $a, o, u$ : Cicero ['Kikero], gĕnu ['genu], 'genoll'; Caesar ['Kai-sar]. I no [*'Sisero], ni [*'TJitfero], ni [*'zenu]. ${ }^{7}$

La $H$, sempre muda. Sembla que va deixar de ser aspirada molt aviat, a principis de la nostra era.

Després de la $Q$, la $U$ es pronuncia sempre: qui [kwi], quoque ['kwokwe], 'també'.

La $S$, sempre sorda, també entre vocals: rosa ['rosa].

Tampoc no canvia la $T$ en cap cas: terra ['terra], gratia ['gra-ti-a], i no ['gratsia], com es fa en la pronúncia romana.

La $V$ és intercanviable amb la $U$, tant de grafia com de so: uentus ['wentus], 'vent'; ueni, ['weni], 'vine'.

La $X$ es pronuncia [ks]: Rex dixit [reks 'diksit] 'El rei digué'.

La $Y$ sempre va ser una lletra estrangera -grega-, i només apareix en manlleus. S'ha de dir com una [i]. ${ }^{8}$

Finalment, els dígrafs $t h, c h, p h$ i $g n$ es pronuncien, respectivament, [t], [k], [f] i [gn]. P.e. agnus ['ag-nus], i no ['anus].

\section{Les vocals, i especialment les es i les os en posició tònica}

Pel que fa a les vocals, les coses no estan tan clares. Les altres llengües, tant en la pronúncia clàssica com en la particular, les fan d'acord amb llur tendència natural, sense tenir en compte la gramàtica històrica llatina. Cosa comprensible, per evitar complicacions.

Ni la $a$, ni la $i$ ni la $u$, tant en posició tònica com àtona, no són cap dificultat ${ }^{9}$. També les es i les $o s$, si són àtones, es poden transcriure senzillament $[\mathrm{e}, \mathrm{o}]$. En canvi, és un problema particular, que interessa vivament l'intèrpret, el de l'obertura o tancament de les es i les os tòniques. Ja avançàvem que aquesta qüestió, les llengües amb una tradició sòlida, la deixen a l'espontaneïtat del parlant. De fet, això és el que acaba recomanant també el professor SEVA per al català (2011: p. 18):

En la meva opinió, cal procurar que la pronunciació catalana del llatí sigui estricta i unitària; ho ha de ser en

7 La transcripció fonètica segueix els criteris de l'Alfabet Fonètic Internacional (en anglès IPA), tal com es troben, p.e., a http://esadir.cat/ ajudatranscripciofonetica\#alfabets.

8 A la grega [y], com la $u$ francesa, només ho pronunciaven en la llengua culta clàssica.

9 Es diu tònica la síllaba que porta l'accent, p.e. la $a$ de nāris 'nas'. Les altres s'anomenen sílllabes àtones: en el cas de nāris, la segona. 
els punts essencials i en els comuns. Ara bé, és del tot admissible — i, a més, inevitable - que es donin algunes variants espontànies, sobretot dialectals: no hi fa res si els uns diuen plènus iflóres i els altres plénus i flòres.

Algú de l'àrea anglo-germànica, doncs, llegirà ĕquidĕm ('certament') amb la primera $e$ tancada, llarga i accentuada ['ekwidem]. De fet, però, eren totes dues breus, i per tant van passar, en llatí tardà, a ser obertes: ['equidem]. Que és el que diria espontàniament un lector italià. Aquest, però, ho obre tot sistemàticament, i obriria també la $o$ de gloria, que havia estat llarga, i que per tant es va convertir en tancada: ['glo-ri-a].

Quina norma es podria establir, que tingui un sentit històric, i no ho deixi a l'arbitrarietat? Cal evitar de totes passades que, a l'hora de pronunciar el llatí, se segueixi caient en l'absurditat de tancar-les totes. L'altre extrem, que segueixen alguns professors catalans que hem consultat, d'obrir-les totes, tampoc no sembla raonable, si bé com a mínim té l'avantatge de no negar la pròpia fonètica. La solució, em sembla, passa per tenir en compte la història del llatí tardà, tal com l'explica al seu article el Dr. SEVA. Aquesta és la baula que vincula el llatí clàssic amb les nostres llengües romàniques. Per això té sentit observar què va passar, en un terreny -l'obertura o tancament de les vocals tòniques- on no podem recórrer al sistema clàssic, perquè era quantitatiu, és a dir, distingia entre vocals breus i llargues, una cosa avui irrecuperable. Sí que podem recórrer, en canvi, a la mateixa evolució que va fer el llatí, històricament. Ho recorda SEVA (2011: p. 14):

El sistema del llatí clàssic comprenia cinc vocals del mateix timbre que podien ser llargues o breus, distinció que més tard es va perdre, alhora que s'incrementaven els timbres vocàlics, i es desdoblaven la $e$ i la $o$ en obertes i tancades.

\section{I, a la pàgina següent:}

En general, en tot el domini llatí, la $e$ llarga del llatí clàssic es converteix en $e$ tancada en llatí tardà, i la $e$ breu, en $e$ oberta; d'aquest estadi parteixen les llengües romàniques.

Curiosament, el català és l'única llengua romànica que ha fet una evolució en molts casos contrària, pel que fa a les es tòniques, i en la regió oriental. P.e. crēere, o plēnus, amb $\bar{e}$ llarga, donen en català oriental creure, i ple, amb $\varepsilon$ ober- $\mathrm{ta}^{10}$. Les altres llengües llatines, en canvi, i en part el català de l'oest, han seguit el llatí tardà, que convertia, si més no en un principi, les vocals llargues en tancades, i les breus en obertes.

Deixant ara de banda com el català oriental i el català occidental han trobat solucions originals i complicades a aquesta norma, la història d'aquestes vocals llatines pot servir de criteri per a les es i os tòniques, en una pronúncia clàssica i catalana que es vulgui escrupolosa. És a dir: Quan la vocal era llarga, es pronuncia tancada, $i$ viceversa.

Això dóna resultats previsibles, com mōns [mons] 'muntanya', tancada perquè era llarga; o pŏntem ['pontem] 'pont', oberta perquè era breu. $\mathrm{O}$ la distinció entre $\bar{o} s$ [os] 'boca' i $\breve{s}$ [os], 'os'. Però també dóna algunes sorpreses, com ara miserěre nōbis [mize'rere 'nobis] 'tingues pietat de nosaltres', on misĕrĕo, 'tenir compassió', té totes dues es breus; la $o$ de nōbis (o de glōria), en canvi, era llarga, encara que l'instint i l'ús modern d'aquests mots ens les hauria fet obrir. Aquesta norma, és clar, també aniria bé per a totes les ocasions en què un català, per no dir qualsevol europeu, s'enfrontés a un text tardollatí. L'inconvenient que té és que requereix l'ús del diccionari, i a vegades, per a les formes verbals, una gramàtica, o la consulta amb un expert. Per això no servirà per a tothom ni en tots els casos.

Finalment, cal examinar la combinació de vocals. I distingir, com en català, entre diftongs, on una de les vocals funciona com a semivocal o semiconsonant, i hiats, on les dues vocals en contacte funcionen com a tals, separadament. Al mot Iulius, cal saber que la primera $I$ és una semiconsonant, i en canvi la segona funciona com una vocal, fent hiat amb la segona $u$ : ['ju-li-us]. Una altra dificultat podria trobar-se en distingir formes com cuius ['ku-jus] i qui [kwi] el primer és genitiu del segon-, on les us i les $i s$ tenen valors ben diferents. Sobre el diftong oe, o $\propto$, escriu SEVA (2011: p. 17):

El diftong oe és poc abundant en llatí clàssic; en llatí tardà evoluciona a $e$ tancada, com la $e$ llarga. Un mot com poena dóna $e$ oberta en català oriental i tancada en occidental; de manera semblant, amoenus.

Per tant, seguint el criteri adés establert, aquests mots es pronunciarien ['pena, a'menus].

Abans d'entrar en la pronúncia del llatí eclesiàstic, i en la del llatí tardà a la catalana, convé aturar-se un moment en la qüestió de l'accent tònic, perquè val per a totes tres variants, i no sempre es pot donar per sabuda.

10 I en la majoria de varietats balears, vocal neutra. 


\section{Com s'accentua el llatí?}

Sembla que l'accent, tant del grec com del llatí clàssic era melòdic, no d'intensitat: la sílllaba tònica hauria sonat una quinta més alta que les àtones. En tot cas, el llatí clàssic distingia entre vocals llargues i breus, i entre síllabes llargues i breus, que no sempre coincideixen. Aquesta complicació es pot entendre com un desig d'aproximar-se al grec clàssic, la màxima referència cultural del món romà. A la pràctica, es va començar a pronunciar amb accent tònic, com fem en les llengües romàniques, bastant aviat: segurament des del s. III. Per això, el llatí clàssic es pronuncia amb un accent sobre la síllaba tònica. Com que als diccionaris corrents aquest accent no es marca, potser serà pràctic de recordar que, segons la norma tradicional, "si l'accent no recau en la penúltima síllaba perquè és breu, recaurà en l'antepenúltima, tant si és llarga com si és breu". ${ }^{11}$ Per tant, en els mots bisil-làbics, l'accent tònic va sempre a la primera síllaba. En els altres, caldrà consultar el diccionari. Exemples: sānŭtās ['sanitas] 'salut', amb l'accent sobre la primera sílllaba perquè la $i$ és breu. Pel mateix motiu, Égăra, 'Terrassa', s'hauria de pronunciar ['egara], també esdrúixola. En canvi, dŏlōsus, 'fal-laç', com que té la segona o llarga, queda [do'losus].

En ocasions, els dubtes no els resol el diccionari, sinó la gramàtica: és el cas de molts verbs, que al diccionari només apareixen enunciats en llurs tres "temes", habitualment present, perfet i supí. En paraules de SEVA (2011: p. 8):

Convé, però, cridar l'atenció sobre els casos variats que presenta la conjugació, sobretot per la tendència que hi ha en català, en castellà i encara més en francès de desplaçar l'accent (convertint els mots d'esdrúixols en plans), cosa que no es dóna en italià. Per exemple, en les diverses formes de libero, el llatí accentua així: (present) líbero, líberas, líberat, liberámus, liberátis, líberant; (imperatiu) líbera, ${ }^{12}$ liberáte; (imperfet) liberábam, liberábas, liberabámus, liberabátis; la tendència (a evitar absolutament) del parlant català, per calc de la seva llengua, és accentuar libéro, libéras, libérant, libéra, liberábamus, liberábatis.

11 Indicació particular del prof. A. SEVA. Que hi afegeix: "La notació prosòdica dels diccionaris està pensada a efectes mètrics: per tant no s'hi indica la quantitat per natura quan contradiu la quantitat per posició. Per exemple, en terra no s'indica res, entenent que la primera síllaba és llarga en mètrica; però fonèticament la $e$ és breu per natura. La quantitat natural, independent de la posició, és pot trobar en diccionaris etimològics, com ara el Dictionnaire étymologique de la langue latine d'A. ERNOUT i A. MEILLET (París, Klincksieck, diverses edicions)."

12 Excel-lent Mozart en l'ofertori del Requiem: [...] líbera ánimas [...] líbera éas [...]. [Nota de SEVA]
Finalment, convé tenir en compte que algunes enclítiques (partícules que s'afegeixen al final d'un mot, com ara -que, -ve, -ne, -dum, -pte, -ce, -dum), atrauen l'accent sobre la síllaba que les precedeix, tant si era llarga com breu. P.e., marĕque s'accentua [ma'rckwe] 'i el mar', per més que la penúltima síllaba sigui breu.

\section{El llatí eclesiàstic del s. XX, pronunciat a la romana}

Per les raons exposades més amunt (\$2), avui l'intèrpret musical català, davant d'un text litúrgic, tendeix a pronunciar les consonants a la romana. En la majoria dels casos, és una mala solució. En quins es podria considerar adequada? Com que es tracta d'una idea que arrenca de Pius $X(1903$ - 1914), caldria que l'obra que es canta o es llegeix fos

- de l'àmbit romà o italià, o que

- es tractés d'una obra litúrgica del s. XX, provinent d'un àmbit geogràfic on no hi hagi una tradició de pronúncia pròpia -p.e. el nostre-, i on l'opció romana fos preferible, per motius especials, a la standard clàssica, i a la catalana tradicional.

Normalment, però, aquesta pronúncia romana s'ha de considerar anacrònica; tant en el llatí litúrgic anterior al s. XX com, encara amb més raó, fora de l'àmbit eclesiàstic. En la majoria de casos, quan la pronúncia clàssica o acadèmica no sigui apropiada, caldria pensar en el llatí tardà, i en la seva adaptació catalana. Això inclou els textos de la litúrgia, si més no fins al s. XX, tant si els imaginem contaminats per una pronúncia castellana -o romana-com si no.

Com que aquesta és la variant més coneguda, i la que ens sembla la menys recomanable, renunciem a especificarne aquí el sistema consonàntic. Apareix ben explicada, p.e., a http://it.wikiversity.org/wiki/Pronuncia_del_latino. I a la taula del final d'aquest article.

\section{Llatí tardà i medieval, pronunciat a la catalana}

Podem estar convençuts que els catalanoparlants dels segles XVI, XVII o XVIII pronunciaven el llatí eclesiàstic d'una forma pròpia i genuïna. En són testimonis grafies com gracias en lloc de gratias, o de seli en lloc de caeli o celi, que es troben tot sovint en manuscrits de misses d'aquell temps, $\mathrm{i}$ fins del s. XIX. Reconstruir i adoptar amb diligència aquesta pronúncia, avui, sembla la cosa més natural, en el procés de reconstrucció nacional en què ens trobem. Si més no per a aquells que veiem en el llatí, i en el català, alguna vigència. En el cas que calgui descartar una pronúncia clàssica, adequada sobretot per a textos clàssics i per a ambients acadè- 
mics, i també una de romana, davant d'un text llatí, litúrgic o no, l'opció lògica hauria de ser aquesta, corresponent al llatí tardà i medieval.

Ja s'han examinat les vocals, en el $\S 5$, a propòsit del llatí clàssic. També s'ha tractat, al $\$ 6$, la qüestió de l'accent tònic, sovint sobreentesa entre els filòlegs. Tots dos aspectes valen per al llatí tardà. Pel que fa a les consonants, només queda reproduir el que escriu Antoni SEVA (2011):

$C$ i $G$ : com en català, fins i tot davant dels antics diftongs ae i oe: caput ['kaput] 'cap'; centum ['sentum] 'cent'; circa ['sirka] 'al voltant'; cōgo ['kogo] 'aplegar, reunir'; gӗnйus ['3e-ni-us] 'geni'; caelum o calum ['sclum] 'cel'; coetus o cotus ['setus], 'encontre'.

$H$ : sempre muda: mihi [mii] 'a mi'; nihil ['niil] 'no res'.

$I, J$ : Cal distingir quan té un valor vocàlic o consonàntic. En tots dos casos, es pronuncia com en llatí clàssic: iam [jam] 'ja'; iйuӗnis ['juvenis] 'jove'.

$G N$ : com en català; agnus ['agnus] 'anyell'; dignus ['dignus] 'digne'.

$Q U:$ La $u$ es pronuncia sempre: quasi ['kwazi]; qui [kwi]; und̆̌quĕ [un'dikwe] 'de per tot arreu'; requiem ['rekwiєm] 'repòs' (en acusatiu); relinquo [re'linkwo] 'deixar'.

$S$ : Com en català: sorda $(s-,-s s-)$ o sonora $(-s$ - intervocàlica, $-s$ si el mot següent comença per vocal): assigno [a'signo] 'assignar'; rīsus ['rizus] 'rialla'; omnes amici ['omnez a'misi].

$S$ - seguida de consonant: s'ha de pronunciar sense $e$ protètica: spiritus ['spiritus], no [*es'piritus] 'esperit'; stătŭo ['sta-tu-o], no [*es'tatuo] 'posar una cosa dreta'.

TI seguides de vocal: com si fos la síl·laba $c i$-: gratia ['gra-si-a]; ratio ['ra-si-o] 'càlcul, proporció'.

$U, V$ : Cal distingir quan té un valor vocàlic o consonàntic. En el segon cas, es pronuncia com a les Balears i Pitiüses, i bona part del País Valencià: vŏlo ['volo] 'voler'; vĕnı̌o ['venio] 'venir, arribar'.
$X$ : SEVA s'inclina per conservar-li el so clàssic [ks], fins i tot en posició intervocàlica: iunxi ['junksi] 'he unit'; dixi ['diksi] 'he dit'; rex [reks] 'rei'.

$Z$ : només es dóna en mots grecs i es pronuncia a la italiana, [tz] o [dz], també en posició inicial: baptizo [bap'tidzo] 'batejar'; Zephyrus ['Tzefirus] 'Zèfir, vent de ponent'.

$\mathrm{CH}, \mathrm{PH}, \mathrm{TH}$ : com en llatí clàssic, respectivament [k, $\mathrm{f}, \mathrm{t}]$.

\section{Conclusió}

En els àmbits en què la pronúncia clàssica no sembla apropiada, o no es coneix, actualment en català es tendeix a pronunciar al llatí a la romana, tant si és un text litúrgic com si no. Convindria recuperar, per al present i per al futur que s'obre als nostres països, una manera catalana de pronunciar el llatí, que faci justícia tant al nostre sistema fonològic, com a la història del llatí tardà. Aquest article, basant-se en la informació que el Dr. Antoni SEVA va publicar el 2011, vol difondre aquesta proposta, i contribuir a reconnectar dues llengües que fins fa relativament poc havien estat íntimament unides. La idea és fer-se útil, especialment a cantants i directors corals que s'enfrontin, des d'una perspectiva catalana -p.e. interpretant música de Joan Pau Pujol, Francesc Valls o qualsevol dels grans compositors del nostre llegat musical-, a la delicada, bonica qüestió de com pronunciarne els textos.

Com a intèrpret, sovint he trobat una coincidència notable entre l'interès que els millors cantants i directors mostren per la dicció, i la qualitat global de llurs interpretacions. El costum de pronunciar el llatí a la romana, i amb les vocals com en castellà, fa pensar en alguns locutors de ràdio, que quan diuen un nom estranger sembla que pensin en la llengua dels veïns. Deixar un costum com aquest, encara que costi un esforç, i substituir-lo per una pronúncia genuïna, és una de les tasques que tenim, com a país en construcció. 


\section{Taula sintètica}

\begin{tabular}{|c|c|c|c|}
\hline & LLATÍ CLÀSSIC & A LA ROMANA & LLATÍ TARDÀ \\
\hline A & [a] & [a] & [a] \\
\hline 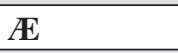 & [ai] & {$[\varepsilon, \mathrm{e}]$} & {$[\varepsilon]$} \\
\hline B & [b] & {$[\mathrm{b}]$} & [b] \\
\hline $\mathrm{Ca}, \mathrm{Co}, \mathrm{Cu}$ & {$[\mathrm{ka}, \mathrm{ko}, \mathrm{ku}]$} & {$[\mathrm{ka}, \mathrm{ko}, \mathrm{ku}]$} & {$[\mathrm{ka}, \mathrm{ko}, \mathrm{ku}]$} \\
\hline $\mathrm{Cæ}, \mathrm{Ce}, \mathrm{Ci}$ & [kai, ke, ki] & {$[\mathrm{t} \varepsilon, \mathrm{te}, \mathrm{ti}]$} & {$[\mathrm{s} \varepsilon, \mathrm{se}, \mathrm{si}]$} \\
\hline Ch & {$[\mathrm{k}]$} & {$[\mathrm{k}]$} & {$[\mathrm{k}]$} \\
\hline D & [d] & [d] & [d] \\
\hline $\mathbf{E}$ & {$[\varepsilon, \mathrm{e}]$} & {$[\varepsilon, \mathrm{e}]$} & {$[\varepsilon, \mathrm{e}]$} \\
\hline $\mathbf{F}$ & {$[\mathrm{f}]$} & {$[\mathrm{f}]$} & [f] \\
\hline Ga, Go, Gu & {$[\mathrm{ga}, \mathrm{go}, \mathrm{gu}]$} & {$[\mathrm{ga}, \mathrm{go}, \mathrm{gu}]$} & [ga, go, gu] \\
\hline Gæ, Ge, Gi & [gai, ge, gi] & [dze, dze, dzi] & {$\left[3 \varepsilon, 3 \mathrm{e}, z^{\mathrm{i}}\right]$} \\
\hline Gn & [gn] & [n] & [gn] \\
\hline $\mathbf{H}$ & {$[\mathrm{h}]$} & $\mathrm{k}$ & (muda) \\
\hline $\mathbf{I}, \mathbf{J}$ & {$[\mathrm{i}, \mathrm{j}, \mathrm{i}]$} & {$[\mathrm{i}, \mathrm{j}, \mathrm{i}]$} & {$[\mathrm{i}, \mathrm{j}, \mathrm{i}]$,} \\
\hline $\mathbf{K}$ & {$[\mathrm{k}]$} & {$[\mathrm{k}]$} & {$[\mathrm{k}]$} \\
\hline $\mathbf{L}$ & {$[1]$} & {$[1]$} & {$[1]$} \\
\hline $\mathbf{M}$ & {$[\mathrm{m}]$} & {$[\mathrm{m}]$} & {$[\mathrm{m}]$} \\
\hline $\mathbf{N}$ & {$[\mathrm{n}]$} & {$[\mathrm{n}]$} & [n] \\
\hline O & {$[0,0]$} & {$[0,0]$} & {$[0,0]$} \\
\hline $\mathbf{E}$ & [oi] & {$[\varepsilon, \mathrm{e}]$} & [e] \\
\hline $\mathbf{P}$ & [p] & [p] & [p] \\
\hline $\mathbf{P h}$ & {$\left[\mathrm{p}^{\mathrm{h}}, \mathrm{f}\right]$} & {$[\mathrm{f}]$} & {$[\mathrm{f}]$} \\
\hline Qua, Quo & [kwa, kwo, kwo] & [kwa, kwo, kwo] & [kwa, kwo, kwo] \\
\hline Que, Qui & {$[\mathrm{kwe}, \mathrm{kw}, \mathrm{kwi}]$} & {$[\mathrm{kwe}, \mathrm{kw}, \mathrm{kwi}]$} & [kwe, kwe, kwi] \\
\hline $\mathbf{R}$ & {$[\mathrm{r}, \mathrm{r}]$} & {$[\mathrm{r}, \mathrm{r}]$} & {$[\mathrm{r}, \mathrm{r}]$} \\
\hline $\mathbf{S}$ & {$[\mathrm{s}]$} & {$[\mathrm{s}, \mathrm{z}]$} & {$[\mathrm{s}, \mathrm{z}]$} \\
\hline$T$ & {$[\mathrm{t}]$} & {$[\mathrm{t}]$} & {$[\mathrm{t}]$} \\
\hline Th & {$\left[\mathrm{t}^{\mathrm{h}}, \theta\right]$} & {$[\mathrm{t}]$} & {$[\mathrm{t}]$} \\
\hline$-\mathrm{ti}$ & [ti] & [tsi] & [si] \\
\hline $\mathbf{U}, \mathbf{V}$ & {$[\mathrm{u}, \mathrm{w}]$} & {$[\mathrm{u}, \mathrm{v}]$} & {$[\mathrm{u}, \mathrm{v}]$} \\
\hline $\mathbf{X}$ & [ks] & [ks] & {$[\mathrm{ks}]$} \\
\hline $\mathbf{Y}$ & [y] & [i] & [i] \\
\hline $\mathrm{Z}$ & [dz] & {$[\mathrm{dz}]$} & [z] \\
\hline
\end{tabular}




\section{El text de l'Ordinari de la Missa, en transcripció fonètica (llatí tardà).}

\section{ORDINARIUM MISS $Æ$}

Kyrie

Kyrie eleison.

Christe eleison.

Kyrie eleison.

\section{Gloria}

Gloria in excelsis Deo

et in terra pax hominibus bonæ voluntatis.

Laudamus te, benedicimus te,

adoramus te, glorificamus te,

gratias agimus tibi

propter magnam gloriam tuam,

Domine Deus, Rex cælestis,

Deus Pater omnipotens.

Domine Fili Unigenite, Jesu Christe,

Domine Deus, Agnus Dei, Filius Patris, qui tollis peccata mundi, miserere nobis;

qui tollis peccata mundi,

suscipe deprecationem nostram.

Qui sedes ad dexteram Patris, miserere nobis.

Quoniam tu solus Sanctus, tu solus Dominus,

tu solus Altissimus,

Jesu Christe, cum Sancto Spiritu:

in gloria Dei Patris. Amen.

\section{Credo}

Credo in unum Deum,

Patrem omnipotentem,

factorem cœli et terræ,

visibilium omnium et invisibilium.

Et in unum Dominum, Jesum Christum,

Filium Dei unigenitum,

et ex Patre natum ante omnia secula.

Deum de Deo, lumen de lumine,

Deum verum de Deo vero.

Genitum, non factum,

consubstantialem Patri,

per quem omnia facta sunt.

Qui, propter nos homines

et propter nostram salutem

descendit de colis.

Et incarnatus est de Spiritu Sancto

ex Maria Virgine, et homo factus est.

Crucifixus etiam pro nobis sub Pontio Pilato;

passus et sepultus est.

Et resurrexit tertia die,

secundum scripturas;

Et ascendit in coelum, ['kirie e'leison

'kriste e'leison

'kirie e'leison]

['gloria in ek'selsis 'deo

$\varepsilon t$ in 'tera paks o'minibus 'bone volun'tatis]

[law'damus te bene'disimus te

ado'ramus te glorifi'kamus te

'grasias 'azimus 'tibi

'propter 'magnam 'gloriam 'tuam

'domine 'deus reks se'lestis

'deus 'pater om'nipotens]

['domine 'fili uni'zenite 'jezu 'kriste]

['domine 'deus 'agnus 'dei 'filius 'patris]

[kwi 'tollis pek'kata 'mundi mize'rere 'nobis

kwi 'tollis pek'kata 'mundi

'sussipe deprekasi'onem 'nostram]

[kwi 'sedes at 'd $\varepsilon k s t e r a m$ 'patris mize'rere 'nobis]

['kwoniam tu 'solus 'sanktus tu 'solus 'dominus

tu 'solus al'tisimus

'jezu 'kriste kum 'sankto s'piritu

in 'gloria 'dei 'patris 'amen]

['kredo in 'unum 'deum

'patrem 'omni po'tentem

fak'torem 'seli et 'tere

vizi'bilium 'omnium et invizi'bilium]

[et in 'unum 'dominum 'jezum 'kristum

'filium 'dei uni'zenitum

et eks 'patre 'natum 'ante 'omnia 'sckula]

['deum de 'deo 'lumen de 'lumine

'deum 'verum de 'deo 'vero]

['zenitum non 'faktum

'konsub stansi'alem 'patri

per kwem 'omnia 'fakta sunt]

[kwi 'propter nos 'omines

et 'propter 'nostram sa'lutem

des'sendit de 'selis]

[et inkar'natus \&st de s'piritu 'sankto

eks ma'ria 'virzine $\varepsilon t$ 'omo 'faktus $\varepsilon s t]$

[krusi'fiksus 'Esiam pro 'nobis sup 'ponsio pi'lato

'pasus $\varepsilon$ t se'pultus $\varepsilon s t]$

[et rezu'reksit 'tersia 'die

se'kundum skrip'turas

et as'sendit in 'selum 
sedet ad dexteram Patris.

Et iterum venturus est cum gloria judicare vivos et mortuos, cuius regni non erit finis.

Et in Spiritum Sanctum

Dominum et vivificantem, qui ex Patre Filioque procedit;

Qui cum Patre et Filio simul adoratur et conglorificatur; qui locutus est per prophetas. Et unam Sanctam Catholicam et Apostolicam Ecclesiam. Confiteor unum baptisma in remissionem peccatorum. Et exspecto resurrectionem mortuorum et vitam venturi sæculi. Amen.

\section{Sanctus-Benedictus}

Sanctus, sanctus, Sanctus Dominus Deus Sabaoth. Pleni sunt cœli et terra gloria tua. Osanna in excelsis.

Benedictus qui venit in nomine Domini. Osanna in excelsis.

\section{Agnus Dei}

Agnus Dei, qui tollis peccata mundi, miserere nobis.

Agnus Dei, qui tollis peccata mundi, miserere nobis.

Agnus Dei, qui tollis peccata mundi, dona nobis pacem. 'sedet at 'deksteram 'patris]

[et 'iterum ven'turus \&st kum 'gloria judi'kare 'vivos $\varepsilon$ ' 'mortuos 'kujus 'regni non 'erit 'finis] [et in 'spiritum 'sanktum 'dominum et vivifi'kantem kwi \&ks 'patre fili' kwi kum 'patre \&t 'filio 'simul ado'ratur \&t 'konglorifi'katur kwi lo'kutus est per pro'fetas] [et 'unam 'sanktam ka'tolikam et apos'tolikam ek'kleziam] [kon'fiteor 'unum bap'tizma in remisi'onem pekka'torum et $\varepsilon$ ks'pekto rezureksi'onem mortu'orum et 'vitam ven'turi 'sckuli 'amen]

['sanktus 'sanktus

'sanktus 'dominus 'deus 'sabaot] ['pleni sunt 'scli et 'tera 'gloria tua o'zana in eks'selsis] [bene'diktus kwi 'venit in 'nomine 'domini o'zana in eks'sclsis]

['agnus 'dei kwi 'tollis pek'kata 'mundi mize'rere 'nobis] ['agnus 'dei kwi 'tollis pek'kata 'mundi mize'rere 'nobis] ['agnus 'dei kwi 'tollis pek'kata 'mundi 'dona 'nobis 'pasem]

\section{Bibliografia}

Alcover, Antoni M., La pronúncia llatina entre catalans. Estudis fonològics. A cura de Nicolau Dols. Publicacions de l'Abadia de Montserrat: Barcelona 2004.

Brittain, Frederick, Latin in Church. The History of its Pronunciation. Cambridge University Press 1934. Parcialment accessible a google books.

Erasme de Rotterdam, De recta Latini Gracique sermonis pronuntiatione. París 1547, accessible en facsímil a http://gallica.bnf.fr/ark:/12148/bpt6k52719t/f2.image.

Herman, József, El latín vulgar. Ariel: Barcelona 1997. (Ed. francesa original 1967)

Herrero, Víctor-José, La lengua latina en su aspecto prosódico. Gredos: Madrid 1971.
McGee, Timothy J., Singing Early Music: The Pronunciation of European Languages in the Late Middle Ages and Renaissance. Indiana University Press 2004.

Seva, Antoni, Viva vox: sobre la pronunciació catalana del llatí tardà, especialment en textos musicals. Revista Catalana de Musicologia, núm. IV (2011), pp. 11-18. Accessible a http://revistes.iec.cat/index.php/RCMus.

Seva, Antoni (dir.), Diccionari Llatí-Català. Diccionaris de l'Enciclopèdia: Barcelona 1993.

Per a l'alfabet fonètic internacional (en anglès IPA), es pot consultar http://web.ku.edu/ cmed/ipafolder/index. html, a més del ja esmentat http://esadir.cat/ajudatrans cripciofonetica\#alfabets. 